\title{
Pendampingan Masyarakat dalam Mewujudkan Keamaan Melalui Program Siskamling Pada Komunitas Peratin Pekon Sukanegara Kabupaten Pesisir Barat Provinsi Lampung
}

\author{
Fathul Mu'in', Eriko Mardiansyah ${ }^{2}$, M. Anwar Nawawi ${ }^{3}$ \\ 1) 2) Universitas Islam Negeri (UIN) Raden Intan Lampung, Indonesia \\ 3) Sekolah Tinggi Agama Islam Tulang Bawang (STAI TUBA), Lampung, Indonesia \\ M Email : fathulmuin@radenintan.ac.id
}

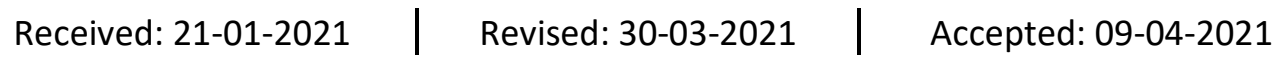

\begin{abstract}
:
Security and public order become the dream of every Indonesian. In realizing the kamtibmas can be done in a variety of ways, one of which is by reviving togetherness and commitment with the community. In this case, the form of community participation Pekon Sukanegara Central Coastal District West Coast District, Lampung Province by conducting environmental security system (Siskamling). Siskamling is a unit that includes components that are interdependent and interconnected and affect each other, which produces the ability to be used as an effort to meet the demands of security and order conditions in the environment. Based on the results of data analysis and discussion, this study concluded that village heads or peratin play a role in the implementation of siskamling. Their role in the implementation of siskamling is as coordinators, facilitators, and motivators. Especially at the time of the burglary there have even been some pekon who complained about the consequences of this theft such as the loss of motorcycles, cars to house break-ins. With this siskamling activity, the village becomes conditioned and avoided theft cases.
\end{abstract}

Keyword: Siskamling, security, Sukanegara

\section{Pendahuluan}

Upaya pencegahan dan penanggulangan tindak pidana bisa dilakukan dengan berbagai cara. Salah satunya adalah dengan kegiatan menghidupkan kembali kebersamaan dan komitmen bersama masyarakat. Dalam hal ini, bentuk partisipasi masyarakat Pekon Sukanegara Kecamatan Pesisir Tengah Kabupaten Pesisir Barat dengan melakukan Sistem Keamanan Lingkungan (Siskamling).

Siskamling merupakan suatu kesatuan yang meliputi komponen-komponen yang saling bergantung dan berhubungan serta saling mempengaruhi, yang menghasilkan daya kemampuan untuk digunakan sebagai salah satu upaya untuk memenuhi tuntutan kebutuhan akan kondisi keamanan dan ketertiban di lingkungan.

Keamanan dan ketertiban masyarakat Pekon Sukanegara ini merupakan suatu kondisi yang harus diciptakan negara dengan setiap warga negaranya, dengan adanya partisipasi dari warga negaranya akan timbul keamanan dan ketertiban yang baik. 
Rumusan permasalahan dalam penelitian ini adalah bagaimanakah upaya penanggulangan tindak pidana pencurian kendaraan bermotor oleh sistem keamanan lingkungan (siskamling) di wilayah Kecamatan Pesisir Tengah dan faktor-faktor apakah sajakah yang menghambat upaya penanggulangan yang dilakukan sistem keamanan lingkungan (siskamling) terhadap tindak pidana pencurian kendaraan bermotor dan mobil di wilayah Kecamatan Pesisir Tengah. Metode atau tekhnik pengumpulan data dalam kegiatan sosialisai ini yaitu dengan mensosialisasikan kepada kelompok masyarakat perpemangku di setiap bagian Desa Suka Negara.

\section{Metode Pelaksanaan}

Penulis melaksanakan pengabdian dengan cara besosialisasi dengan warga masyarakat desa sukanegara untuk memberi informasi dan menyadarkan diri bahwa dalam pelaksanaan siskamling ini betujuan untuk mengamankan desa/pekon sukanegara, penulis menetapkan beberapa orang sample untuk dijadikan peserta sosialisasi yang dilaksanakan di balai pekon Sukanegara atas dasar kerja sama dengan pihak aparat desa setempat. Teknik pengumpulan data dalam penelitian ini adalah dengan mensosialisaikan serta ditunjang dengan sesi tanya jawab dengan peserta sosialisai. Teknik analisis data yang digunakan dalam penelitian ini adalah teknik analisis deskriptif yaitu dengan cara menangkap secara objektif temuan-temuan di lapangan yang dibantu oleh informasi dari kepala desa/peratin. kemudian diintepretasikan dengan kalimat-kalimat atau pertanyaanpertanyaan yang mudah dipahami dari para peserta. Kegiatan sosialisasi ini dilaksanakan dibalai desa pekon sukanegara pada hari jumat 7 agustus 2020 dan dalam pelaskanaan kegiatan sosialisasi ini hanya berdurasi 2.5 jam dari jam 09:00-11:30 WIB.

\section{Hasil dan Pembahasan}

Siskamling merupakan upaya bersama dalam rangka meningkatkan sistem keamanan dan ketertiban masyarakat. Sistem keamanan lingkungan merupakan bentukbentuk swakarsa yang merupakan suatu kesatuan komponen yang saling bergantung dan berhubungan, saling memengaruhi untuk memenuhi rasa aman di masyarakat dan untuk mendukung terwujudnya masyarakat yang adil, makmur, dan beradab berdasarkan Pancasila dan UUD 1945. Dalam pelaksanaan siskamling biasanya dilakukan dengan ronda. Ronda merupakan kegiatan atau aktivitas berkeliling kampung untuk menjaga keamanan dan ketertiban desa setempat.

Upaya yang dilakukan dalam meningkatkan keamanan dan ketertiban masyarakat adalah dengan mengadakan sistem keamanan lingkungan atau biasa disebut siskamling. Seperti yang telah dijelaskan sebelumnya di desa sukanegara telah mengadakan siskamling. Pelaksanaan siskamling ini sudah dilaksanakan sejak bulan juni 2015 karena adanya perintah dari kepolisian dan bupati kabupaten pesisir baratc untuk mengadakan kembali siskamling di setiap kampung yang ada di Kabupaten Pesisir Barat, karena maraknya kasus gangguan keamanan yang terjadi di kabupaten pesisir barat, seperti yang telah terjadi yaitu pencurian sepeda motor, mobil dan rumah yang dimasuki oleh pelaku untuk melakukan aksi kriminalnya. 
Adapun aktivitas pelaksanaan siskamling di desa sukanegara ini masih belum maksimal karena kurangnya partisipasi masyarakat dalam kegiatan siskamling ini. Disamping itu, keamanan dan ketertiban masyarakat sedang mulai menurun khususnya di desa rawas dan sukajadi karena ada warga yang mengeluh kehilangan sepeda motor dan di desa wayredak yang mengeluh telah kehilangan. Sehingga dalam hal ini perlu adanya peran kepala desa/peratin dalam menggerakkan warganya dan meningkatkan nilai gotong royong diantara warga untuk turut serta dalam pelaksanaan siskamling ini agar desa sukanegara inimenjadi aman dan ada personil polisi atau koramil yang membantu dalam pelaksanaan siskamling, desa suakanegara tetap dapat aman dengan adanya kerjasama diantara warga.

\section{Pengertian dan Peranan Siskamling}

Menurut Tontowi Amsia (2013:70) "Siskamling merupakan salah satu upaya dalam menciptakan suasana atau kondisi suatu lingkungan yang aman" Dan menurut Peraturan Kepala Kepolisian Republik Indonesia No. 23 Tahun 2007 pasal 1 ayat 6 "sistem keamanan lingkungan yang selanjutnya disingkat siskamling adalah suatu kesatuan yang meliputi komponen-komponen yang saling bergantung dan berhubungan serta saling mempengaruhi, yang menghasilkan daya kemampuan untuk digunakan sebagai salah satu upaya untuk memenuhi tuntutan kebutuhan akan kondisi keamanan dan ketertiban di lingkungan".

Menurut Kartono (1994 : 33) "kepala atau pemimpin adalah Seorang pribadi yang memiliki kecakapan dan kelebihan khususnya kecakapan kelebihan di satu bidang, sehingga dia mampu mempengaruhi orang-orang lain untuk bersama-sama melakukan aktivitas-aktivitas tertentu, demi pencapaian satu atau beberatujuan". Menurut UU No. 6 Tahun 2014 pasal 1 Desa adalah desa dan desa adat atau yang disebut dengan nama lain, selanjutnya disebut desa, adalah kesatuan masyarakat hukum yang memiliki batas wilayah yang berwenang untuk mengatur dan mengurus urusan pemerintahan, kepentingan masyarakat setempat berdasarkan prakarsa masyarakat, hak asal usul, dan/atau hak tradisional yang diakui dan dihormati dalam sistem pemerintahan Negara kesatuan Republik Indonesia. Menurut UU No. 6 Tahun 2014 pasal 6 ayat (2) berbunyi" penyebutan desa atau Desa adat sebagaimana dimaksud disesuaikan dengan penyebutan yang berlaku didaerah setempat" Seperti halnya yang berada di Kecamatan pesisir barat penyebutan untuk desa adalah pekon.

\section{Perencanaan Siskamling}

Menurut Nanang Fattah (2008:49) “ perencanaan merupakan tindakan menetapkan terlebih dahulu apa yang akan dikerjakan, bagaimana mengerjakannya, apa yang harus dikerjakan, dan siapa yang mengerjakannya Sesuai dengan adanya pelaksanaan program siskamling maka kepala desa/peratin memerlukan suatu proses perencanaan yang dilakukan bersama perangkat desa. 
Menurut peraturan kapolri no. 23 tahun 2007 beberapa hal yang harus terdapat dalam suatu pos kamling adalah:

1. Merumuskan prosedur dan tata cara tuntunan praktis

2. Merumuskan jadwal penugasan siskamling

3. Membuat panel kegiatan mingguan dan harian yang berisikan:
a. Tujuan kegiatan
b. Uraian kegiatan
c. Petugas pelaksana
d. Jadwal pelaksanaan
e. Catatan hasil pelaksanaan

1. Buku catatan/mutasi kegiatan petugas

2. Sistem Alarm dan sistem komunikasi yang disediakan sesuai kemampuan warga

3. Perlengkapan P3K, penanggulangan bahaya dan bencana seta peralatan lain yang dirasakan perlu.

\section{Pengorganisasian Siskamling}

Pengorganisasian yaitu suatu proses dimana pekerjaan diatur dan dibagikan di antara para anggota, sehingga tujuan organisasi itu dapat tercapai secara efektif dan efisien. Sesuai dengan Peraturan Kepala Kepolisian Republik Indonesia No. 23 Tahun 2007 pasal 3 menyatakan bahwa siskamling dibentuk berdasarkan kesepakatan dalam musyawarah warga, dengan berasaskan semangat budaya kekeluargaan, gotong royong, dan swarkarsa. Sehingga dalam hal ini dalam pembagian kerja dan koordinasi pekerjaan dalam siskamling itu disusun berdasarkan kesepakatan bersama dengan adanya asas kekeluargaan, agar tidak terjadinya suatu perselisihan di antara warga dalam melaksanakan siskamling ini.

\section{Penggerakan Siskamling}

Penggerakan adalah suatu tindakan untuk mengusahakan agar semua anggota kelompok berusaha untuk mencapai sasaran sesuai dengan perencanaan manajerial dan usaha-usaha organisasi. Seperti yang dijelaskan Husein Umar (2000:77) berbagai definisi pergerakan:

1. Directing, yakni menggerakkan orang lain dengan memberikan pengarahan

2. Actuating, yakni menggerakkan orang lain dalam artian umum

3. Leading, yakni menggerakkan orang lain dengan cara menempatkan diri di muka orangorang yang digerakkan, membawa mereka ke suatu tujuan tertentu serta memberikan contoh-contoh

4. Commanding, yakni menggerakkan orang lain disertai dengan unsur paksaan

5. Motivating, yakni menggerakkan orang lain dengan terlebih dahulu memberikan alasanalasan mengapa hal itu harus dikerjakan.

\section{Pengawasan Siskamling}

Pengawasan merupakan suatu proses untuk memastikan bahwa semua aktivitas yang terlaksana telah sesuai dengan apa yang telah direncanakan sebelumnya. Pengawasan merupakan coercion atau compeling artinya proses yang bersifat memaksa- 
maksa agar kegiatan-kegiatan pelaksanaan dapat disesuaikan dengan rencana yang telah ditetapan.

\section{Analisis}

Kepala desa/peratin merupakan pemimpin penyelenggaraan pemerintahan desa yang memiliki kewajiban membina dan memelihara ketentraman dan ketertiban desa serta membina dan meningkatkan kesejahteraan masyarakat desa. Untuk itu kepala desa/peratin mengadakan siskamling untuk meningkatkan ketertiban dan ketentraman masyarakat desa. Dalam pelaksanaan siskamling kepala desa memiliki tugas perencanaan siskamling, pengorganisasian siskamling, penggerakkan siskamling, dan pengawasan siskamling. Hal ini dilakukan agar pelaksanaan siskamling di desa sukanegara dapat berjalan sesuai dengan tujuan yang diinginkan yakni desa menjadi aman.

Kepala desa atau Peratin desa Sukanegara melaksanakan peranannya dalam perencanaan siskamling sebagai koordinator yakni melakukan pertemuan sebelum melaksanaan siskamling, kemudian ikut serta dalam penjadwalan, dan siapa saja yang wajib melaksanakan siskamling. Perencanaan yang dilakukan di desa sukanegara adalah dengan pendekatan Bottom up planning yaitu proses perencanaan yang dilakukan dari tingkat bawah agar mendapat persetujuan dari manajemen puncak yakni dari kepala dusun ke kepala desa/peratin.

Kemudian dalam pengorganisasian siskamling Pekon Sukanegara telah melakukan tugasnya sebagai koordinator yakni seperti adanya pembagian kerja serta koordinasi pekerjaan dalam pelaksanaan siskamling. Ketika terdapat masalah keamanan di pekon, maka kepala kampung juga memilliki tugas untuk menyelesaikan konflik apabila konflik tersebut tidak dapat ditangani oleh kepala dusun.

Kepala Pekon atau Peratin juga telah melakukan penggerakan siskamling sebagai motivator dan fasilitator yakni dengan pemberian motivasi atau pemberian contoh untuk mengikuti siskamling dengan rajinnya kepala kampung dalam berkeliling kampung serta mengunjungi warga yang tidak ikut serta dalam melaksanakan siskamling. Dan kepala pekon juga sebagai fasilitator dalam hal penggerakan siskamling, kepala pekon memperhatikan adanya peralatan yang kurang memadai untuk menunjang pelaksanaan siskamling agar menjadi baik seperti pos kamling yang kurang, kendaraan untuk melakukan patroli, dan peralatan lainnya.

Kepala Pekon pun melakukan pengawasan siskamling sebagai pengawas yakni dengan berkeliling kampung setiap malam untuk meninjau pelaksanaan siskamling di Pekon Sukanegara telah berjalan sebagaimana mestinya. Kepala Pekon juga bertanya kepada petugas siskamling tentang partisipasi warga dalam siskamling.

Kepala pekon memang harus berperan dalam pelaksanaan siskamling karena siskamling merupakan salah satu cara dalam meningkatkan keamanan dan ketertiban masyarakat. Hal ini sesuai dengan kewajiban dari kepala kampung yang tertuang dalam UU No. 6 Tahun 2014 yakni adanya kewajiban kepala kampung dalam memelihara ketentraman dan ketertiban masyarakat kampung/desa. 
Dalam hal ini agar pelaksanaan siskamling dapat dijalankan lebih maksimal maka kepala kampung memberikan peralatan untuk siskamling yang sesuai dengan Peraturan Kepala kepolisian Republik Indonesia No. 23 Tahun 2007 seperti ditambahnya pos kamling dan peralatan lainnya.

\section{Kesimpulan}

Berdasarkan hasil analisis data dan pembahasan yang telah diuraikan mengenai peranan kepala desa/peratin dalam pelaksanaan siskamling di Pekon Sukanegara Kecamatan Pesisir Tengah, Kabupaten Pesisir Barat, penulis dapat menyimpulkan bahwa kepala desa/peratin berperan dalam pelaksanaan siskamling. Peranan kepala desa/peratin dalam pelaksanaan siskamling adalah sebagai koordinator, fasilitator, serta motivator. dengan kondisi yang seperti sekarang ini yang sedang marak marakya dengan adanya pencurian bahkan sudah ada beberapa desa yang mengeluhkan akibat dari pencurian ini seperti kehilangan sepeda motor, mobil hingga pembobolan rumah.

Dengan adanya kegiatan siskamling ini, desa menjadi terkondisikan dan terhindar dari kasus pencurian. Adapun dampak dari kegiatan ini yaitu dapat membantu menyadarkan partisipasi para warga desa/pekon akan pentingnya menjaga keamanan lingkungan bersama demi menghindari dari hal-hal yang tidak diinginkan, dengan menjaga tiga pintu masuk ke desa/pekon sukanegara ini dan berkeliling secara bergiliran untuk memastikan keamanan wilayah desa sukanegara.

\section{Daftar Pustaka}

Amsia, Tontowi. 2013. Kewarganegaraan dalam Ketahanan Nasional. Lampung: KDT

Arikunto, Suharsimi. 2014. Prosedur PenelitianSuatu Pendekatan Praktik. Jakarta: Rineka Cipta.

Fattah, Nanang. 2008. Landasan Manajemen Pendidikan. Bandung : PT. Remaja Rosdakarya.

Kartono, Kartini. 1994. Pemimpin dan Kepemimpinan. Jakarta: Rajawali Pers.

Peraturan Kepala kepolisian Republik Indonesia No. 23 Tahun 2007 Tentang Sistem Keamanan Lingkungan

Sangadji dan Sopiah. 2010. Metodologi Penelitian. Yogyakarta: Andi

Sarwono, Sarlito Wirawan. 2011. Teori-Teori Psikologi Sosial. Jakarta: PT Raja Grafindo Persada.

Sudjana. 2005. Metode Statistika. Bandung: PT. Tarsito Bandung

Umar, Husein.2000. Riset Pemasaran dan Perilaku Konsumen. Jakarta: PT Gramedia Pus. 